A look at the region

\title{
Rescuing the Past - Preventive Archaeology and Archeoenviromental Services, Labrys, o. p. s., Czech Republic
}

\author{
Milan Kuchař́ik $\mathrm{a}^{*}$ \\ ${ }^{a}$ Labrys, o. p. s., Hloubětínská 16/11, 19000 Prague 9, Czech Republic
}

\section{ARTICLE INFO}

\section{Article history:}

Received: $21^{\text {st }}$ August 2016

Accepted: $21^{\text {st }}$ November 2016

\section{Keywords:}

preventive archaeology

anthropology

osteology

paleobotany

stratigraphic seqences

\begin{abstract}
A B S TRACT
The non-governmental organisation Labrys, o. p. s., was established in 2006 as a private research establishment focusing mainly on preventive archaeology. The Labrys Company focuses on a wide spectrum of activities related to research on historic monuments, primarily on rescue archaeology and associated scientific research activities. The mainstays of our activities are the increase of archaeological capacities in the regions of the Czech Republic, field research of ancient and medieval stratigraphic locations, standardisation of processes in archaeology, and the multidisciplinary research of our cultural heritage.
\end{abstract}

\section{Aim and scope of the company}

Labrys Company focuses on a wide spectrum of activities related to the research of historic monuments, primarily on preventive archaeology and scientific research activities in the Czech Republic. From the very beginning, we have directed our activities towards multidisciplinary environmental research. Building on our projects to rescue historic monuments in 2011, we have expanded our activities into fields that focus on standing architectural monuments (historical building research).

The mainstays of our activity are the increase of archaeological capacities in the region, field research on prehistoric sites and medieval stratigraphic locations, standardisation of processes in field archaeology, and multidisciplinary research of cultural heritage.

\section{Institutional history}

The non-governmental organisation Labrys, o. p. s., was established in 2006 as a private research institution focusing mainly on preventive archaeology (or "rescue" archaeology).

*Corresponding author. E-mail: kucharik@labrys.cz
Between 2006 and 2008 we operated exclusively in Prague. In 2009 we expanded to the Hradec Králové and Pardubice regions and later to the rest of the Czech Republic.

It was our goal to implement and intensify functional preventive archaeology in the Czech Republic region where this type of research activity is still rather underdeveloped.

\section{Organisation structure and employees}

Currently, the company is comprised of its headquarters and the departments of field research, project preparation, environmental research, and internal services. Headquarters is in charge of administrative support while the department of project preparation communicates with investors, prepares research, and reports on territorial archaeological studies including prospecting the terrain. The department of field research uses specialists to conduct excavations. The department of environmental research ensures preparation, expert evaluation of samples, and drawing up of assessments. The department of internal services is in charge of the conservation, documentation, and proprietary record keeping of archaeological findings. At the moment, there are two workplaces in Prague, one in Dvưr Králové nad Labem, and the other in Pardubice. 
The company has twelve permanent professional employees: seven archaeologists, a geologist, an anthropologist, an archaeozoologist, and two archaeobotanists. There are ten other employees on the technical staff. During the season, we hire up to 120 workers for our field activity.

\section{Preventive archaeology}

Preventive archaeology is the process of protecting the archaeological heritage from landscape planning and onto rescue excavation. During the longest building boom in Czech Republic's history (until 2008) we completed up to 450 field research projects a year, ranging from small-scale supervision to large-scale excavation. Currently, we conduct about 150 field research projects a year. Between 2011 and 2014, our main activity was rescue research completion for structures financed by EU Structural Funds. This period included rescue archaeological excavations associated with the revitalisation of historical sites, such as: Litomyšl Castle (Figures 1, 2), Kuks Hospital, the Benedictine Monastery in Broumov and Sázava Glassworks. Major projects have included research on the heart of medieval cities, the revitalisation of the central square and adjacent streets in Dvůr Králové nad Labem, the reconstruction of the Municipal Court in Prague and reconstruction of the Museum of Decorative Arts in Prague, which uncovered an abundance of large collections of medieval and early modern findings. Significant research on the transportation infrastructure includes the extension of the tramline Podbaba - ČD Podbaba
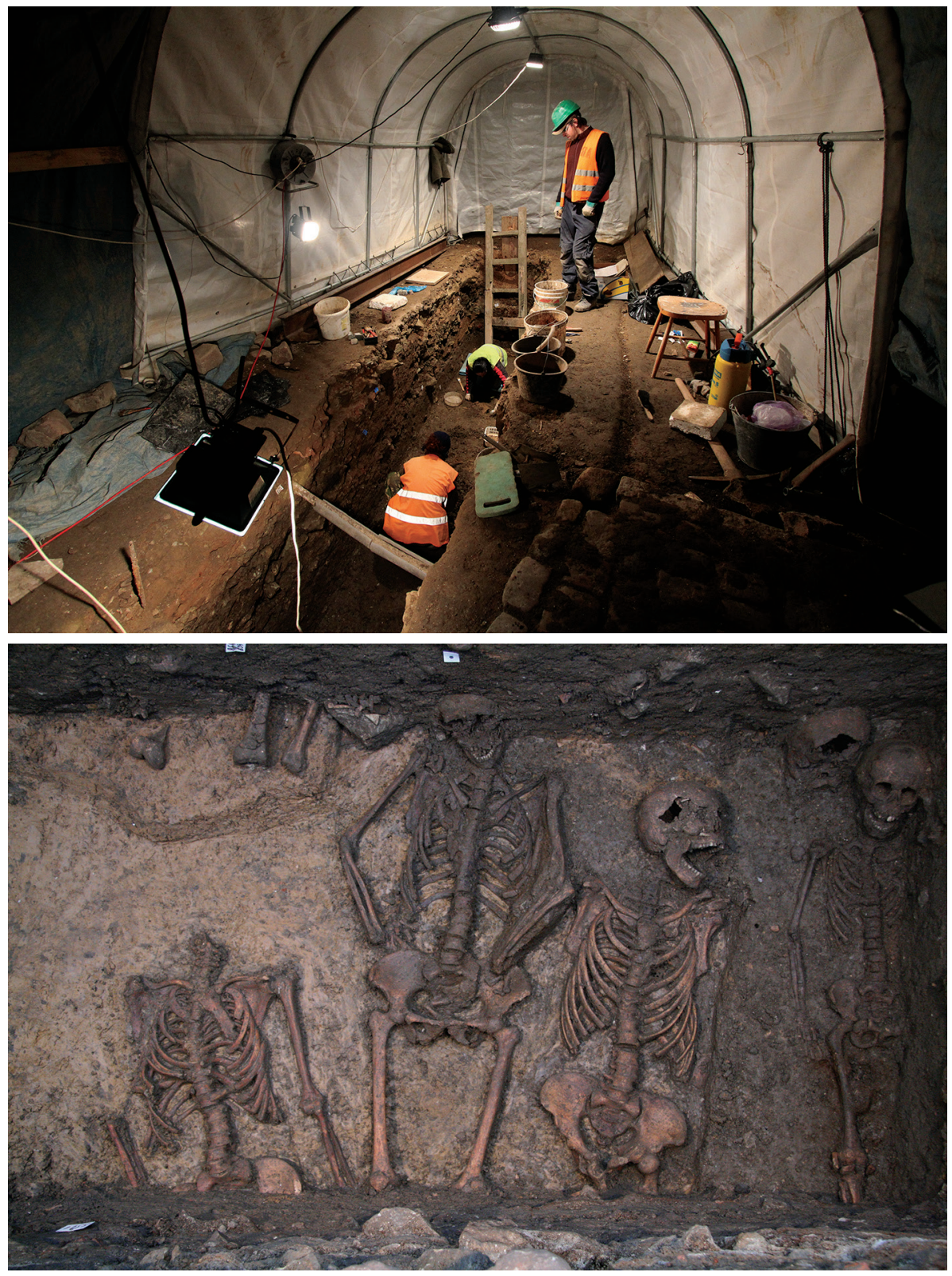

Figure 1. The basic sources of our research are our own rescue excavations. Litomyšl, rescue excavation of medieval graveyard at the church of St. Kliment, $13^{\text {th }}-15^{\text {th }}$ century.

Figure 2. Litomyšl, Zámecké návrší - a trench through the Medieval graveyard at the church of St. Kliment, $13^{\text {th }}-15^{\text {th }}$ century. 
Figure 3. Praha 8, Karlín. Probably a brickmaking furnace in the industrial suburb of Prague, $18^{\text {th }}-19^{\text {th }}$ century.

Figure 4. Paleoenvironmental data acquisition. Rescue excavation of small stream basin with prehistorical settlement; 5-m-thick sediments in the pit of the construction works of a railway tunnel, Kyšice, West Bohemia.
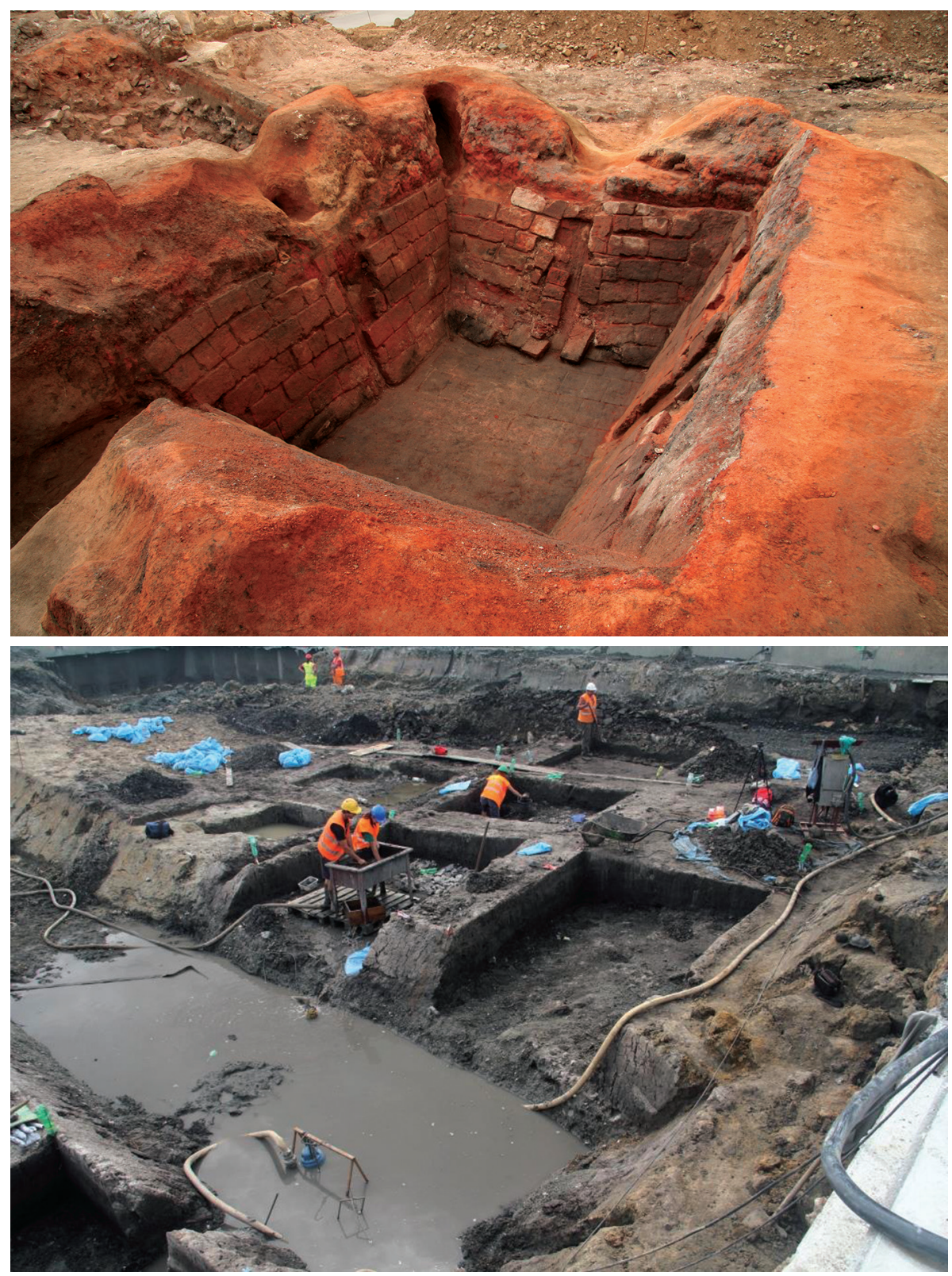

in Prague with its rich polycultural archaeological layers and the new railway connection Rokycany - Plzeň with its many findings of ancient terrain and artefacts (Figure 4). The archaeological prospecting of road R35 from Jičín to Hradec Králové, which included terrain examination, aerial photography, and analysis of map and archive data, is the most significant undertaking of our terrestrial archaeological studies.

We seek to systematize and standardize archaeological research and processes through the implementation of modern documentation methods. This is related to our efforts to implement standard solutions within the framework of control and decision-making processes in the management of archaeological research, the use of digital recording and measurement technology (photogrammetry, GNSS), and the processing of archaeological data while retaining their formal and spatial properties (database and CAD).

\section{Long-term research projects}

Our current research activity is mainly based on our own rescue excavations between 2006 and 2010, from which, among others, we have several long-term projects. The most detailed is from the burial site of the Migration Period in Prague-Zličín (2005-2008). The Grant Agency of the Czech Republic financed the projects of "Multiregional Contacts during the Migration Period" and the "Natural Environment, Health Condition and Mobility - a multidisciplinary approach to the study of the Migration Period burial site". The Pro Archeologia Saxonia Foundation financially supports the catalogue of the same burial site. The other parts of this project are a popular science book and an exhibition called Barbarian Graves The World of the Living and the Dead of the Migration Period at Prague-Zličín (2015-2016). 


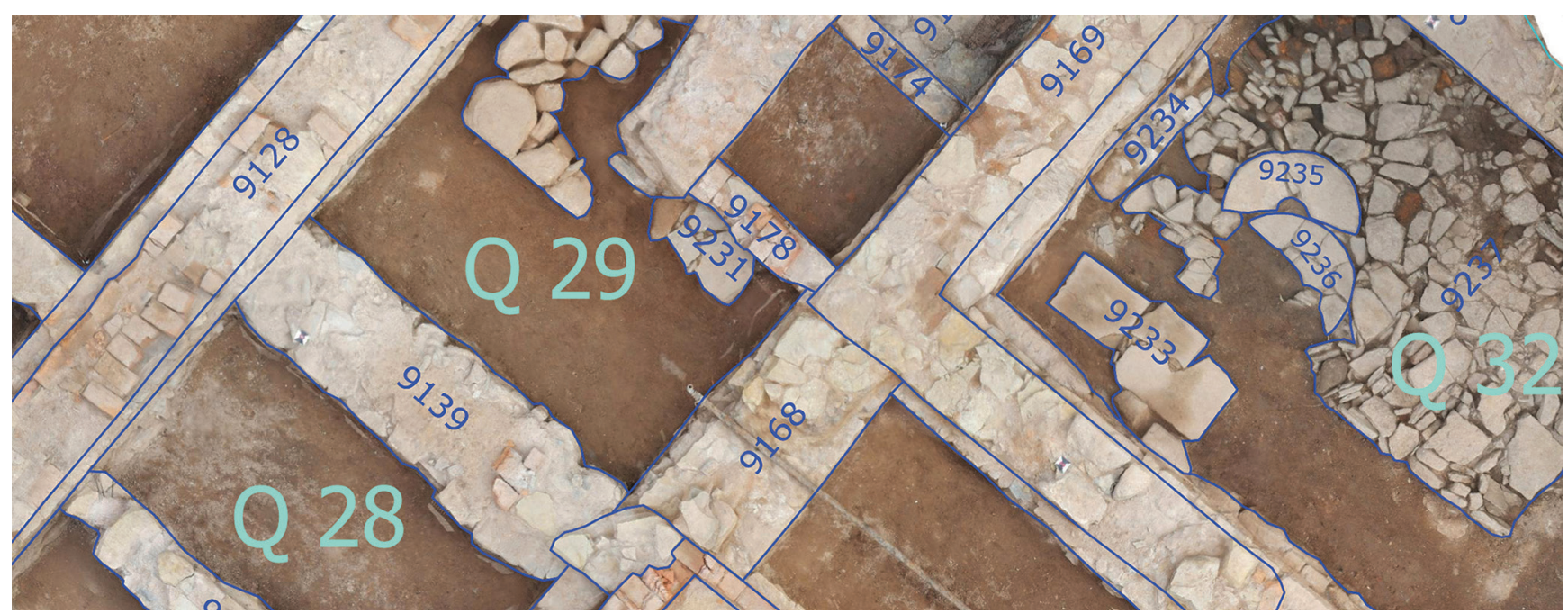

Figure 5. Medieval buildings in the city centre - field documentation, Náchod, East Bohemia.

There are other long-term research projects which focus on specific topics, such as: Research on Ancient Polycultural Formation on the Banks of the Vltava River; and the Beginnings and Development of Medieval Towns in Podkrkonoší (Figure 5); and others. We have recently tried to incorporate industrial premises $\left(18^{\text {th }}-19^{\text {th }}\right.$ centuries $)$ of the Czech Republic into archaeological research (Figure 3). At present, we are focusing on Prague suburbs (Karlín).

\section{Other Activities}

As part of our scientific research, we occasionally organise thematic conferences such as: Computer Support in Archaeology (2010); and Research, Protection, and Presentation of Architectural Ruins (2012). In 2012, we also established cooperation with foreign partners by a series of international workshops which were focused on the Migration Period and the glass vessels from this period (BohemianBajuvarian Forum, Regensburg; Trinken und Trinkengefässe im Germanischen altertum, Prague). In connection with our present research projects, we are cooperating with foreign research establishments (e.g. the RömischGermanische Zentralmuseum Mainz, Bayrisches Landesamt für Denkmalpflege Münech und Regensburg, Bayrische Staatssammlung für Anthropologie und Paläoanatomie München, Johannes Guttenbeg Univesität Mainz).

\section{Presentation and Popularisation}

From 2006, information about us, including our current research projects, has been available on our website (www. labrys.cz); in 2010 we also set up a Facebook profile (@labrysarchaeology). Between 2012 and 2013 we sent by email a newsletter concerning our activities, which was also distributed in a printed form to expert committees, workshops, and fairs.
We annually participate in the Prague fair called "Monuments" where our company has a display promoting our status as one of the archaeological organisation in the Czech Republic.

We naturally organise lectures for schools, the public, and occasionally for interest groups. We also present ourselves at museum exhibitions for which we act as co-organisers and provide expert commentary. The largest recent exhibitions have been: A Journey to the Depth of the City, or 12 Archaeological Discoveries in Prague (2011); Poodhalená tajemství Dvora Králové (Partially Discovered Mysteries of Dvưr Králové, 2011); Barbarian Graves (2015-2016); and Treasures of the Barbarians (2016).

\section{The Company's Contribution}

We are convinced that our greatest contribution has been the intensification of the care and regard for archaeological cultural heritage in the regions where we work, and for the new job opportunities, we have created. Furthermore, we have promoted interdisciplinary cooperation in the humanities, natural sciences, and technical fields at a single working environment, as well as the opening up of new topics. At present, we are the only private establishment focusing on archaeological heritage in the Czech Republic.

\section{Selected references}

BUREŠ, M., PLEINEROVÁ, I., JIŘÍK, J., KUCHǍ̌ÍK, M. 2008: Nové poznatky k osídlení západního okraje Prahy v 5. století, Barbarská sídliště. In: Droberjar, E., Komorćzy, B., Vachůtová, D. (Eds.): Chronologické, ekonomické a historické aspekty jejich vývoje ve světle nových archeologických výzkumů (Archeologie barbarů 2007). Spisy ARÚ Brno 37, 201-232.

HORÁKOVÁ, M., JAROŠOVÁ, I., VÁVRA, J., JIŘÍK, J., KUCHǍ̌ÍK, M. 2014: Food strategies during the migration period: A study of the Prague - Zličín population. In: Mikulov anthropology meeting 2014. The Dolní Věstonice Studies 20, 159-162. 
JIŘÍK, J., VÁVRA, J., ŠMOLÍKOVÁ, M., KUCHAŘÍK, M. 2015: Hroby Barbaru. Praha.

KUCHAŘíK, M., KUBÁLEK, P. 2009: Laténský kostrový hrob v Praze Schollerově ulici. Archeologica Pragensia 19, 129-136.

KUCHAŘÍK, M., KVIETOK, P., HORÁK, J., KUBÁLEK, P., HOLUB, M. 2009: Birituální pohřebiště kultury zvoncových pohárů v Praze Jinonicích. Archaeologia Pragensia 19, 5-30.

VÁVRA, J., JIŘÍK, J., JAROŠOVÁ, I., VÍŠKOVÁ, M., KUBÁLEK, P., KUCHAŘ́lK, M. 2012: The migration period burial site in Prague - Zličín, Czech Republic, Preliminay report. Zeitschrift für Archäologie des Mittelalters 40, 1-25.
VÁVRA, J., JIŘÍK, J., KUBÁLEK, P., KUCHAŘÍK, M. 2007: Pohřebiště z doby stěhování národů v Praze - Zličíně, ul. Hrozenkovská - průběžná zpráva o metodice a výsledcích výzkumu. In: Droberjar, E., Chvojka, O. (Eds.): Archeologie Barbarů 2006 - Přispěvky z II. protohistorické konference České Budějovice, 21.-24.11. 2006. Archeologické výzkumy v Jižních Čechách Supplementum 3, svazek II., 565-577.

VÍŠKOVA, M., JAROŠOVA, I., JIŘIK, J., VÁVRA, J., KUCHAŘÍK, M. 2012: Populace z doby stěhování národů z pohřebiště v Praze-Zličíně z pohledu fyzické antropologie a archeologie. Sborník národního muzea v Praze, Řada A-Historie 66/3-4, 61-70. 
